Title: Adjectival forms in Middle English. Syntactic and semantic implications.

Authors: Isabel Moskowich-Spiegel Fandiño \& Begoña Crespo García. Institution: Dept. of English Philology. University of La Coruña.

Address: Facultade de Filoloxía. Campus de Elviña s/n. 15071-A Coruña.

E-mail: imoskowich@udc.es, bcrespo@udc.es 


\section{Adjectival forms in Middle English. Syntactic and semantic implications.}

\section{Introduction}

Our main purpose in this paper is to look into the place of adjectives in a particular period in the history of English as regards their position in the Noun Phrase and whether such position may somehow alter the meaning of the adjective and of the NP itself. To this end, only adjectives in an attributive function both as premodifiers or postmodifiers of the head will be considered. ${ }^{1}$

In section 1 we will briefly attempt to draw a line between the class "adjective" and other morphological classes considering different viewpoints. Section 2 will be devoted to the consideration of word-order as one of the factors characterising adjectives inside the NP and how their position may alter the meaning of the whole phrase.

The next step in our research will be embodied in section 3 where we will present the corpus material for our study taken from the Middle English part of the Helsinki Corpus of English Texts and section 4 will provide the analysis of the data obtained from our evidence.

Section 5 will finally supply our conclusions. We will attempt -if possible - to find an explanation grounded on syntactic and semantic criteria for the different shades of meaning found to depend on position.

\section{Delimitation of the class "adjective"}

Adjectives are easily distinguishable from nouns and verbs in English even for non-trained people (Bhat 1994:11) and though we certainly believe they form a separate word-class, we also agree with Rusiecki (1985:1) when he describes the adjective in English as "a fuzzy category, which can only be defined by a set of complementary criteria, morphological and syntactic, some of which apply to all adjectives, and some to certain adjective classes only". Therefore, we do believe that there are different types of adjectives or, in other words, that some adjectives are more central (that is to say, they fulfil a larger number of tests such as being gradable, the very-test, etc.) whereas others are more peripheral inside their own class. ${ }^{2}$ 
Generally speaking, and according to some scholars, the only external mark English adjectives seem to have as almost exclusive of their class is gradability (Quirk et al. 1985:403) though this is not always so straightforward. Gradability is

seen as such an essential property of adjectives that many writers include it in their definition of the category (...) without accounting for those legitimate members of the category which are non-gradable (Raskin \& Nirenburg 1998:151).

In fact, the majority of attributive-only adjectives are non-gradable (Rusiecki 1985:3) and thus, gradability should not be considered as a characteristic typical of adjectives. It seems to be a semantic feature that is syntactically constrained.

The relation established between adjectives and the head of the NP in which they occur is one of dependence since adjectives are regarded as elements used to characterise other words. In Jespersen's terms (1949) we could say that the function of adjectives is that of adjunct (or secondary word) used to define a principal (or primary word). In this respect, forms that externally exhibit the features of adjectives may not be adjectives from a strictly syntactic point of view if they stand alone with the article as in example (1):

(1) the rich

Moreover, adjectives obtained from verbs such as the one illustrated in example (2) seem to behave in a slightly different way.

(2) a smiling face

In fact, some authors (Borer 1990:102-103) conclude that forms in -ing, even those that cannot be modified by the adverb very, are adjectives. Borer adds:

the restriction on the distribution of very does not stem from the categorial nature of expressions such as jumping but instead is a property of the verb from which these expressions are derived. ${ }^{3}$

Though further research is needed in relation to this point, we will consider $-e d$ forms similar to -ing ones as far as their adjectival character is concerned even though the "very-test" cannot be applied as shown in (3).

(3) *the very dead 
In our consideration of the class adjective we will not enter the question already mentioned by others (Rusiecki 1985:2) of the real difference, if any, between determiners and adjectives of the certain-type in cases such as (4). The latter have been all excluded from our survey.

(4) a certain person

\section{Word-Order and meaning}

Word order is another defining factor for the class "adjective". Apart from the nature of the adjectival category itself, the ordering of elements within the Noun Phrase is that on which we will focus our attention in this paper. In 1963 Greenberg first attempted to systematise the different types. One of the determining factors of such typological classification was the relative order of "secondary" constituents regarding that of the "primary" ones such as SVO.

He claimed (1963:61) that "the position of demonstratives, articles, numerals, and quantifiers (e.g., 'some', 'all'), frequently differs from that of the qualifying adjective". Minor orderings, so to call them, are related to the word-order of major constituents. In this sense, Universal 17 of Greenberg's says: "With overwhelmingly more than chance frequency, languages with dominant order VSO have the adjective after the noun".

In like manner, the order in which the Adjective occurs pre-nominally seems to corresopond to type III (SOV), languages that may have either Adjective + Noun or Noun + Adjective. However, the principle by which the order of secondary elements must be harmonic with that of main constituents (harmony principle) enables Greenberg to justify the order Adjective + Noun we find in English even though it is not a type III, but a type II language.

As a matter of fact, besides these typological constraints there seem to exist others of a semantic nature upon the ordering of adjectives and nouns within the Noun Phrase that need being dealt with here. In this sense, Greenberg recognises that the fact that Noun + Adjective appears as the predominant order in the languages examined by him is a consequence of the general tendency for comment to follow topic. From this same sentence perspective, Markus (1997) resorts to the communicative weight of certain elements within the sentence to account for the possibility of a different word order and the subsequent semantic variations.

Likewise, there seems to be some semantic restriction on word order in the sense that an adjective may refer to two different things depending on whether it is pre- or postposed to its head. In Spanish (5a)

(5a) un gran hombre 
does not mean the same as $(5 b)$

(5b) un hombre grande

While the adjective in (5a) refers to a characteristic of the man's personality, (5b) refers to his size. Similarly, English shows a clear difference between the meaning of "responsible" in (6)

(6a) the responsible man

(6b) the man responsible

Also dealing with the ordering of adjective and noun, König (1971) among others has suggested that preposed adjectives are used to refer to a durative or possible state whereas post-position implies temporary relevance. This same viewpoint is adopted by Bolinger (1967: 3) when he affirms that (7a)

(7a) the stolen jewels

denotes characteristic and $(7 b)$

(7b) the jewels stolen

expresses action.

\section{Corpus Material}

In order to verify whether ordering was already affecting meaning in earlier stages of the English language, we resorted to data from the Middle Ages. It was our intention to pay particular attention to those Noun Phrases containing the same adjectival form in a different position (either before or after the noun).

All the fragments of texts used for the present study belong to the Helsinki Corpus of English Texts. Diachronic Part. ME IV was the period selected for this survey, that is to say, the period stretching from 1420 to 1500, a time in which the French influence is well-established and many changes in the inflexional system of the language have already taken place. All types of texts gathered by the compilers of the Corpus have been dealt with. Extracts of ca. 3,000 words have been selected thus totalling some 45,000 words (just for a first approximation to the topic). Our corpus has been then organised as shown in table 1 below: 
Table 1. Word count for each type of text

\begin{tabular}{|c|c|c|}
\hline Type of text & Title & Words \\
\hline Law & $\begin{array}{l}\text { Statutes (II). The Statutes of the Realm } \\
(\text { part of }<\text { sample } 1>\text { ) }\end{array}$ & 2378 \\
\hline Documents & Indenture, petitions (M4) $(<$ sample $3>$ ) & 2232 \\
\hline $\begin{array}{l}\text { Handbooks, } \\
\text { medicine }\end{array}$ & $\begin{array}{l}\text { The Liber de Diversis Medicinis (<sample } \\
2>\text { ) }\end{array}$ & 2799 \\
\hline $\begin{array}{l}\text { Handbooks, } \\
\text { others }\end{array}$ & $\begin{array}{l}\text { Reynes, The Commonplace Book }<\text { sample } \\
1><\text { sample } 4>\end{array}$ & 2058 \\
\hline $\begin{array}{l}\text { Handbooks, } \\
\text { astronomy }\end{array}$ & Metham's Days of the Moon & 2902 \\
\hline $\begin{array}{l}\text { Science, } \\
\text { medicine }\end{array}$ & $\begin{array}{l}\text { The Cyrurgie of Guy de Chauliac (<sample } \\
2>\text { ) }\end{array}$ & 3080 \\
\hline Sermons & $\begin{array}{l}\text { ME Sermons ed. from Ms. Royal } \\
\text { 18B.XXIII (not complete sample) }\end{array}$ & 2710 \\
\hline Rules & $\begin{array}{l}\text { Aelred of Rievaulx's De Institutione } \\
\text { Inclusarum }\end{array}$ & 1972 \\
\hline $\begin{array}{l}\text { Religious } \\
\text { treatises }\end{array}$ & $\begin{array}{l}\text { The Book of Margery Kempe (chapter } 2 \text { in } \\
<\text { sample } 2>\text { ) }\end{array}$ & 2291 \\
\hline Prefaces & $\begin{array}{l}\text { Caxton, Prohemye and epilogue of } \\
\text { Polichronicon }\end{array}$ & 2175 \\
\hline History & Gregory's Chronicle $(<$ sample $1>$ ) & 2759 \\
\hline Biography & $\begin{array}{l}\text { Life of Saint Edmund (not complete } \\
\text { sample) }\end{array}$ & 3211 \\
\hline Fiction & $\begin{array}{l}\text { Caxton's The History of Reynard the Fox } \\
\text { (part of }<\text { sample } 1>\text { ) }\end{array}$ & 2119 \\
\hline Romances & Malory's Morte Darthur $(<$ sample $1>)$ & 3892 \\
\hline Drama & Ludus Coventriae $(<$ sample $2>)$ & 2270 \\
\hline Letters, private & $\begin{array}{l}\text { Two letters by Clement Paston (in } \\
<\text { sample } 2>\text { ) }\end{array}$ & 1856 \\
\hline $\begin{array}{l}\text { Letters, } \\
\text { private }\end{array}$ & $\begin{array}{l}\text { William Paston (part of the "Memorandum } \\
\text { to Arbitrators") }\end{array}$ & 2496 \\
\hline Bible & $\begin{array}{l}\text { Rolle's The Psalter of Psalms of David } \\
(<\text { sample } 6>)\end{array}$ & 2251 \\
\hline Total & & 45451 \\
\hline
\end{tabular}

Of course, not all adjectival forms have been included in our selection. We have excluded those on table 2 as well as other forms whose lexical content does not denote a specific characteristic and that normally precede the head of 
the Noun Phrase (that is to say, non-qualifying adjectives and those forms of the certain-type mentioned in section 1 above).

Table 2. Forms excluded from the analysis

non-qualifying forms mani, swylk, sum

Prepositional sense during, accordaunt, outtaken, ago, a go

With regard to the controversial -ed forms, we may be prompted to include some of these into the class of adjectives (at least for our purpose here) as "on the whole, adjectives can only be coordinated if they belong to the same semantic class" (Aarts 1982:109) and we can find instances of the so-called "pure" (or central) adjectives coordinated with participles (or peripheral) such as the one in example (8):

(8) a difficult but well built story

Nevertheless, we have disregarded the participles that function as prepositions, almost all of them due to French influence and whose adjectival character has already been lost in Middle English (see Table 2 above).

\section{Analysis of data}

Table 3. presents the distribution of adjectives in the selected corpus as follows: the first and second columns - "type of text", "total words"-are merely descriptive and indicate the different types of text included in the fourth part of the Middle English period, and the total number of words each fragment contains, respectively. The remaining columns - "adjectives", "attributive adjectives", "preposed adjectives", "postposed adjectives"- present actual results in two different ways: by using raw figures and by their corresponding percentages with regard to the previous total number.

Hence, in a corpus of 45,451 words we have found 2,222 adjectives which correspond to $4.8 \%$ of the total number of words. Of all the adjectival forms, 1,515 occur in an attributive position which corresponds to $68.2 \%$ of the total number of adjectives. The vast majority of these 1,515 attributive adjectives occupy a prenominal position: 1,418 which represents the $93.6 \%$ of the total amount of attributive adjectives, whereas only 97 occur postnominally, that is to say, the remaining $6.4 \%$.

Table 3. Distribution of adjectives in the corpus 


\begin{tabular}{|c|c|c|c|c|c|c|c|c|c|}
\hline \multirow[t]{2}{*}{ Type of text } & \multirow[t]{2}{*}{$\begin{array}{l}\text { Total } \\
\text { words }\end{array}$} & \multicolumn{2}{|c|}{ Adjectives } & \multicolumn{2}{|c|}{$\begin{array}{l}\text { Attributive } \\
\text { adjectives }\end{array}$} & \multicolumn{2}{|c|}{$\begin{array}{l}\text { Preposed } \\
\text { adjectives }\end{array}$} & \multicolumn{2}{|c|}{$\begin{array}{l}\text { Postposed } \\
\text { adjectives }\end{array}$} \\
\hline & & $\mathrm{n}$. & $\%$ & n. & $\%$ & n. & $\%$ & n. & $\%$ \\
\hline Law & 2378 & 185 & 7.7 & 170 & 91.9 & 156 & 91.8 & 14 & 8.2 \\
\hline Documents & 2232 & 57 & 2.6 & 49 & 85.9 & 41 & 83.7 & 8 & 16.3 \\
\hline $\begin{array}{l}\text { Handbooks } \\
\text { medicine }\end{array}$ & 2799 & 111 & 3.9 & 72 & 64.9 & 67 & 93.1 & 5 & 6.9 \\
\hline $\begin{array}{l}\text { Handbooks } \\
\text { others }\end{array}$ & 2058 & 96 & 4.6 & 54 & 56.2 & 46 & 85.2 & 8 & 14.8 \\
\hline $\begin{array}{l}\text { Handbooks } \\
\text { astronomy }\end{array}$ & 2902 & 230 & 7.9 & 50 & 21.7 & 47 & 94 & 3 & 6 \\
\hline $\begin{array}{l}\text { Science, } \\
\text { medicine }\end{array}$ & 2710 & 113 & 4.2 & 51 & 45.1 & 51 & 100 & 0 & 0 \\
\hline Sermons & 2710 & 101 & 3.7 & 60 & 59.4 & 54 & 90 & 6 & 10 \\
\hline Rules & 1972 & 125 & 6.3 & 89 & 71.2 & 85 & 95.5 & 4 & 4.5 \\
\hline $\begin{array}{l}\text { Religious } \\
\text { treatises }\end{array}$ & 2291 & 78 & 3.4 & 54 & 69.2 & 54 & 100 & 0 & 0 \\
\hline Prefaces & 2175 & 167 & 7.6 & 140 & 83.8 & 133 & 95 & 7 & 5 \\
\hline History & 2759 & 85 & 3.1 & 79 & 92.9 & 74 & 93.7 & 5 & 6.3 \\
\hline Biography & 3211 & 146 & 4.5 & 113 & 77.4 & 111 & 98.3 & 2 & 1.7 \\
\hline Fiction & 2119 & 80 & 3.7 & 59 & 73.7 & 53 & 89.8 & 6 & 10.2 \\
\hline Romances & 3892 & 146 & 3.7 & 91 & 62.3 & 86 & 94.5 & 5 & 5.4 \\
\hline Drama & 2270 & 113 & 4.9 & 68 & 60.2 & 59 & 86.8 & 9 & 13.2 \\
\hline $\begin{array}{l}\text { Letters, } \\
\text { private }\end{array}$ & 1856 & 41 & 2.2 & 26 & 63.4 & 25 & 96.2 & 1 & 3.8 \\
\hline $\begin{array}{l}\text { Letters, } \\
\text { non-private }\end{array}$ & 2496 & 237 & 9.4 & 227 & 95.7 & 214 & 94.3 & 13 & 5.7 \\
\hline Bible & 2251 & 111 & 4.9 & 63 & 56.7 & 62 & 98.4 & 1 & 1.6 \\
\hline Total & 45451 & 2222 & 4.8 & 1515 & 68.2 & 1418 & 93.6 & 97 & 6.4 \\
\hline
\end{tabular}

It is obvious that not all types of texts show the same amount of adjectives and this may be due, on the one hand, to the style of the author and, on the other, to the type of text itself. In this sense it is not surprising that private letters are the ones showing fewer adjectives $(2.2 \%)$, since they are mainly informative and not descriptive pieces. However, "non-private letters" are in the lead with more than $9 \%$ of qualifying adjectives. The explanation for the high count of adjectives in this particular text may be that of the total of attributive adjectives found in non-private letters (227), 149 are examples of the pre-posed past participle seyd as in (9).

(9) the seyd William 
As regards pre- and post-position, preposed adjectives greatly outnumber those in post-position (as is to be expected). A greater number of preposed adjectives does not necessarily imply a greater number of postposed instances. Nevertheless, of the three types of text containing a greater amount of pre-head adjectives, i.e. "law", "prefaces" and "letters-non private" only the second does not coincide with those that exhibit the greatest amount of postposition, namely, "law", "drama" and "letters non-private".

The coincidence in "law" and "letters non-private" may be explained if we pay attention to the very nature of these text-types. In both cases the use of legal formulae and/or adjectives of French origin (postposed attributive adjectives of the so-called French-type) seem to favour post-position. As for "drama", though further investigation is needed to achieve definitive conclusions, we could suggest that it may be verse and end-rhyme in Ludus Coventriae that forces post-position in many cases though most of our instances have, once more, an originally French element such as the suffix able.

At this point it is worth mentioning that the only text-type in which no post-head attributive adjectives have been found is "medicine" in a translation from Latin of a text by Guy de Chauliac. It is well known that Latin has the order Adjective + Noun and this pattern seems to have been translated and easily assimilated into English as something absolutely natural.

Of all the attributive adjectives in the corpus only a small number are found occupying a position before and after the head in different phrases. Obviously in all examples the Adjective + Noun pattern corresponds to the normal word order. The reasons that can account for the post-position of these same adjectives, from our point of view, fall into two categories that we have labelled as semantics-oriented and syntax-oriented reasons.

\subsection{Semantics-oriented reasons}

Since adjectives, like any other word-class with lexical content, can be decomposed into the several semantic features that conform its meaning, we have tried to apply this method to attributive adjectives both in pre-and postposition to see whether we can trace any difference between them. Evidence from this analysis points to the fact that there exists just a slight difference, a shade of meaning which helps distinguish pre and post-position. This contrast seems to be a matter of temporary relevance as opposed to durative state (Konig 1971). The relationship, then, is one of partial opposition. Examples (10) to (13) are proof of this statement: 
(10b) that it is mooste fayre to men mortalle (Caxton, Prohemye of Polychronicon)

(11a) publyke wele (Caxton, Prohemye of Polychronicon)

(11b) of the wele publyke (Caxton, Prohemye of Polychronicon)

(12a) +torowe synne presente in tis liffe (ME Sermons ed. from Ms.Royal 18 B.XXIII)

(12b) of thys present trete tyme (Gregory's Chronicle $<$ sample 1>)

(13a) if +ter be bane broken (The Liber de Diversis Medicinis $<$ sample 2>)

(13b) +te broken banes (The Liber de Diversis Medicinis <sample $2>$ )

In (10a) mortal characterises $l y f$, it indicates a permanent, stable and durative quality of lyf. In (10b) mortalle is restricting the range of reference of the noun. It is not to all men that something is mooste fayre, rather it is to men mortalle.

The same can be said of (11a) and (11b). Once again, the contrast lies in the opposition permanent/temporary state as Bolinger (1967) highlighted in his article concerning attribution and predication. Pre-position accounts for permanence, durability, the whole wele is publycke. Predication can help us prove this meaning. On the contrary, in the wele publycke the adjective restricts the meaning of the noun wele, not all wele is publycke, just part of it and what we are talking about is this wele that is publicke. (Relative-clause transformation has been used for this interpretation).

The fact that posthead adjectives can be expanded and reinterpreted as the predication of a restrictive relative clause with the linking verb be may lead us to regard those adjectives in post-position as the only manifestation of a reduced relative clause that has undergone reduction due to the principle of economy of languages. Sadler and Arnold (1994:194) use this idea to claim that postnominal adjectives are essentially predicative: 
It is often observed that postnominal adjective constructions have interpretations like (reduced) relative clauses, the rivers navigable being equivalent to the rivers which are navigable, modulo the tense expressed by the verb. Relative clauses, of course, involve predicative (postcopula) adjectives, hence the claim that postnominal adjectives are 'predicative'.

They also make four observations to support their idea:

a) Certain adjectives which cannot occur in a predicative position cannot occur after the noun either as in the case of former in (14 $)$ and (14b):

(14a) *policemen former

(14b) *Those policemen are former

b) If the adjective occurring pre- and post-nominally exhibits different senses, it is the predicative sense that appears in a postnominal position as in (15) below:

(15a) The present editors

(15b) The editors present

(15c) The editors are present

c) A prenominal adjective plus a noun can form an idiomatic expression whereas this is not possible with postnominal and predicative adjectives. (16a), (16b) and (16c) below illustrate this point:

(16a) A white lie

(16b) *a lie white and without malice

$(16 c) * a$ lie which is white

d) There is a restriction on prenominal comparative constructions that does not affect postnominal or predicative comparatives as can be seen in the examples under (17):

$(17 a) * a$ taller man than my mother

(17b) a man taller than my mother

$(17 \mathrm{c})$ the man is taller than my mother 
However, from our point of view, the main difference that can be found between postnominal and predicative adjectives is of a semantic nature: postnominal adjectives act as noun modifiers whereas predicative adjectives are genuine predicatives:

In particular, if nouns are interpreted as properties, adjective noun combinations must also be interpreted as properties, and adnominal APs must be interpreted as functions from properties to properties (whether they are prenominal or postnominal). If sentences denote propositions, then predicative adjectives have to denote open propositions or functions to propositions; if sentences are taken to denote states of affairs, then predicative adjectives have to denote parameterized states of affairs (Sadler and Arnold 1994:194-195).

At any rate, a combination of syntactic and semantic criteria can be applied to examples (12a) and (12b). From a semantic standpoint, in (12b) present(e) means "current" whereas in (12a) it implies location "the sinn that is" in a particular place, "in this liffe" (Sadler and Arnold 1994). From a syntactic point of view presente in (12a) occurs postnominally because of the adverbial that modifies it (Bailey 1987). If we take into account that the adverbial is a place adverbial we could conclude that the extension of the adjective is to a certain extent required by the significance of the adjective proper. It is then, a sort of vicious circle, semantic justifications call for syntactic ones and viceversa.

There is just one example of an -ed form occurring before and after a noun. It is the case of broken in (13a) and (13b). In (13a) the -ed adjective-like form, adds information, indicates a characteristic of the noun it goes with. In (13b) the $-e d$ form indicates action, it exhibits more verb-like properties than in the previous example because of its relationship with the passive voice. Bolinger illustrates this difference with stolen in the stolen jewels and the jewels stolen (1967:3) in (7).

As for-ing forms no coincident instances have been traced.

\subsection{Syntax-oriented reasons}

From the point of view of syntax we should classify our examples according to the various constraints on word-order or depending on the constructions that precede or follow the adjective. 
(a) If what precedes the adjective is an indefinite pronoun, post-position is compulsory as in (18b) and (19b) as opposed to (18a) and (19a):

(18a) oure swete Lorde Ihesus (ME Sermons ed. from Ms.Royal 18 B.XXIII)

(18b) ther is no thynge swetter (Aelred's De Institutione Inclusarum)

(19a ) prouffytable lawes (Caxton, Prohemye of Polychronicon)

(19b) ther is no thynge profitabler (Aelred's De Institutione Inclusarum)

(b) If what follows the adjective is either

a) a complement as in (20b):

(20a) a clene knyght (Malory's Morte Darthur <sample 1>)

(20b) but is of lyff clennere $+\tan$ she Cast (Ludus Coventriae $<$ sample 2>)

b) or a coordinated element as in the b-examples from (12) to (23):

(21a) just sentence (Ludus Coventriae $<$ sample 2>)

(21b) ... than have we cause bothe juste and Able ffor a fals man (Ludus Coventriae < sample 2>)

(22a) many other worthy men (Indenture, petitions (M4) < sample $3>$ )

(22b) make ryght pryvate men digne \& worthy (Caxton, Prohemye of Polychronicon) 
(23a) that thou sholdist noo temperal good haue (Aelred's De Institutione Inclusarum)

(23b) of the lordes sp uall and tep ell (Statutes (II), The Statutes of the Realm $<$ sample $1>$ )

In such cases post-position is compulsory.

In examples (18b) and (19b) post-position after an indefinite pronoun is explained on sentence perspective grounds (Markus 1997). Indefinite pronouns as heads of Noun Phrases have little communicative or rhematic weight in comparison with the adjective. This is the reason why the adjective remains in second position and the pronoun comes first. In these two examples there may be a further reason: the complementation of the adjective that occurs when using comparative structures that follow it as in (20b).

As has already been mentioned, another syntactic pattern that forces post-position is the coordination of two adjectives. In these cases the endweight principle also plays a part. The informative weight of both adjectives surpasses the communicative relevance of the nominal head. (23b) illustrates the post-position of attributive adjectives of the so-called French type. It is a sort of formulaic expression with words of Latin/French origin that occurs repeatedly in law texts. This example represents Mustanoja's claim (1960:277) that legal formulae are those in which the so-called French type is more often found.

We have also found certain instances of what could be termed "false coordination of adjectives acting postnominally". Examples (24) and (25) could be included within this group:

(24a) the rede blode (The life of St.Edmund <not complete sample>)

(24b) of white wynne or rede un-to +te third party (The Liber de Diversis Medicines $<$ sample 2>)

(25a) +ti precious blode (ME Sermons, ed. From Ms. Royal 18 b. XXIII)

(25b) by +te propre +tinges and preciouse (The Cyrurgie of Guy de Chauliac $<$ sample $2>$ ) 
They do not embody true adjectival coordination but noun phrase coordination with the head of the second NP omitted, either the true nominal head or the corresponding pro-form. Therefore, the accurate counterparts of examples (24b) and (25b) would be something like (24b1) and (25b1).

(24b1) of white wynne or rede wynne/one

(25b1) $\quad+$ te propre + tinges and preciouse + tinges/ones

One case of coordination of two NPs with their respective adjectives occurring postnominally has also been found in (26):

(26) to suffyr deth gret and vengeauns Able but also thystoryes able (Ludus Coventriae < sample 2>)

The need to keep the balance between the two Noun Phrases functioning as direct objects can justify the repetition of the post-position. It may be interpreted as a sort of structural equilibrium demanded by the stylistic apparatus of a versified text.

Besides what has been commented on so far, there are three examples in our corpus that need to be dealt with separately. They are examples (27) to (29). In (27b) the function of dede is not clear because of the type of main verb. The verb see can act either as a transitive or as a complex-transitive verb and in this case the two interpretations are possible.

(27a) a dede corse (Malory's Morte Darthur < sample 1>)

(27b) he saw thes two bodyes dede (Malory's Morte Darthur $<$ sample 1>)

(27b1)he saw thes two bodyes dede (Malory's Morte Darthur $<$ sample 1>)

In (27b1), the whole sequence "thes two bodyes dede" is an NP functioning as direct object; inside this NP, "dede" is a postposed attributive adjective: "thes two dede bodyes"

(27b2) he saw thes two bodyes dede (Malory`s Morte Darthur $<$ sample $1>$ ) 
In (27b2) the verb see is complemented by an NP functioning as direct object "thes two bodyes dede" and an Adjective Phrase that acts as a complement of the object, "dede". Verbs of perception such as see, hear, observe, etc. admit this kind of construction in which the -ed form acts predicatively. The fact that "dede" is verb-like fosters this second interpretation. ${ }^{4}$

(28a) in quyet the prelatis semys wyse men (Rolle's The Psalter of Psalms of David $<$ sample 6>)

(28b) +te seyd Walter hath nothyr title suffisaunt ne right in no maner wyse by ony matier (William Paston, part of the Memorandum to Arbitrators)

In (28b) the occurrence of a downtoner such as "in no maner" favours the post-position of the adjective it modifies. Although Markus (1997:494-495) claims that modification of a discourse marker is not enough for an adjective to occur in a post-head position, things are not so straightforward in this case where everything points to the preeminence of what he calls "object communication" over "metacommunication".

(29a) on the next morning (Two letters by Clement Paston $<$ sample 2>)

(29b) the fryday next after the fest (Two letters by Clement Paston $<$ sample 2>)

Finally, in (29b) we have an example of post-position because there is another sequence after the adjective which increases its communicative weight. Contrary to what happens in (20b) where post-position is compulsory, (29b) illustrates a case of optional post-position. The reason is the type of element that follows the adjective in each case since in (29b) what we are presented with is an adverbial modifying the adjective "next" whose order can be altered (Bailey 1987:152) rather than a complement.

\section{Conclusions}

The abundant instances of pre-head adjectives found in our corpus confirm that Middle English between 1420 and 1500 was already an Adjective + Noun 
language although in certain text-types of official or legal nature instances of post-position can also be found mainly due to French influence. In the "drama" type there is a further conditioning that can help us explain the occurrence of postposed adjectives: they are written in verse and, therefore, post-position may be explained alluding to the stylistic requirements of versified texts.

Almost all the examples analysed can be grouped according to either semantic or syntactic criteria and evidence shows that both criteria are interwoven when searching for a logical reasoning behind post-position: the adjective itself does not alter its meaning but restricts the range of reference of the whole NP in which it is immersed. The temporariness feature put down to postnominal adjectives changes the general sense of the NP but we know it limits the scope of the NP because it can be transformed into a restrictive relative clause.

These semantic-syntactic explanations depict the actual situation of sequences containing post-head adjectives when compared with pre-head ones. The description can be completed with reasons that penetrate into the speaker's intention. At this point, pragmatic factors such as those related to sentence perspective or metacommunicative theory (communicative or rhematic weight, the end-weight principle) can act as justifications. Hence, in order to finally analyse the phenomenon of postposed adjectives, a set of pragmalinguistic considerations are to be taken into account.

\footnotetext{
1 We understand attributive adjectives in the same sense as Aarts (1997:32), that is to say, those used to supply more information about the character, nature or state of the noun.

${ }^{2}$ Similarly it is well known that some adjectives can be used in an attributive function only whereas others can be found as predicative only. See example (14).

3 In this connection, compare the two -ing forms in *very jumping and very interesting.

4 As Bailey (1987:151) puts it: "Marked environments may reverse expectations regarding an attributive or predicative participle. Following a verb of perception, one expects the predicative form as in 'He saw a girl crying' vs. marked 'He saw a crying girl"'.
}

\section{References}

Aarts, F. \& Aarts, J. 1982. English Syntactic Structures, Functions and Categories in Sentence Analysis. Oxford: Pergamon Press.

Anderson, J. 1993. "Parameters of Syntactic Change: A Notional View". Historical Linguistics: Problems and Perspectives ed. by Ch. Jones, 142. London: Longman. 
Baker, C.L. 1989. English Syntax. Cambridge, Mass: The MIT Press.

Bailey, Ch-J. N. 1987. "Attributive and Predicative: Form and Order". Arbeiten aus Anglistik und Amerikanistik 12:2. 147-154.

Bhat, D.N.S. 1994. The Adjectival Category. Criteria for Differentiation and Identification. Berlin: Mouton de Gruyter.

Bichakjan, B.H. 1987. "The Evolution of Word-Order: A Paedomorphic Explanation". Papers from the $7^{\text {th }}$ International Conference on Historical Linguistics ed. by A. Giacalone Ramat et al., 87-108. Amsterdam \& Philadelphia: John Benjamins.

Bolinger, D. 1967. "Adjectives in English: Attribution and Predication". Lingua 18. 1-34.

Borer, H. 1990. "V+ing. It Walks like an Adjective, It Talks like an Adjective". Linguistic Inquiry 21:1 95-103.

Canale, M. 1976. "Implicational Hierarchies of Word-Order Relationships". Current Progress in Historical Linguistics ed. by W.M. Christie. 39-70. Amsterdam: North-Holland.

Fisiak, J. 1968. A Short Grammar of Middle English. Part One: Graphemics, Phonemics and Morphemics. London: Oxford University Press.

Greenberg, J.H. 1963. "Some Universals of Grammar with Particular Refernce to the Order of Meaningful Elements". Universals of Language ed. by J.H. Greenberg. 58-90. Cambridge, Mass: The MIT Press.

Jespersen, O. 1949. A Modern English Grammar on Historical Principles. London: Allen and Unwin.

Kisbye, T. 1971. A Historical Outline of English Syntax. Aarhus: Nordisk Sprogog Kulturforlag.

König, E. 1971. Adjectival Constructions in English and German: A Contrastive Analysis. Heidelberg: Goos.

Kortmann, B. 1991. Free Adjuncts and Absolutes in English. Problems of Control and Interpretation. London: Routledge.

Lass, R. 1987. The Shape of English. Structure and History. London: Dent.

Levin, B. \& Rappaport, M. 1986. "The Formation of Adjectival Passives". Linguistic Inquiry 17:4. 623- 661.

Markus, M. 1997. "The Men Present" vs "The Present Case": Word-Order Rules Concerning the Position of the English Adjective". Anglia 115. 487-506.

Mustanoja, T. 1960. A Middle English Syntax. Helsinki: Societé Néophilologique.

Quirk, R. et al. 1985. A Comprehensive Grammar of the English Language. London: Longman.

Raskin, V. \& Nirenburg, S. 1998. "An applied Ontological Semantic Microtheory of Adjective Meaning for Natural Language Processing", Machine Translation 13:2-3. 135-227. 
Rusiecki, J. 1985. Adjectives and Comparison in English. A Semantic Study. London: Longman.

Sadler, L. \& Arnold, D.J. 1994. "Prenominal Adjectives and the Phrasal/Lexical Distinction”. Journal of Linguistics 30. 187-226.

Sørensen, K. 1989. "On Adjectives in -ing and -y". Essays on English Language in Honour of Bertil Sundby ed. by L.E. Breivik, A. Hille \& S. Johansson. 335-366. Oslo: Novus Forlag. 